\title{
Kuivikkeen vaikutus hevosen hyvinvointiin
}

\author{
Susanna Särkijärvi1 ${ }^{1)}$, Seppo Hyyppä ${ }^{1)}$, Anniina Karvinen ${ }^{2)}$ ja Markku Saastamoinen ${ }^{1)}$ \\ ${ }^{1)}$ MTT/Hevostalous, Varsanojantie 63, 32100 Ypäjä, etunimi.sukunimi@mtt.fi \\ ${ }^{2)}$ Helsingin yliopisto, kotieläintieteen laitos, PL 28, 00014 Helsingin yliopisto
}

\section{Johdanto}

Suomessa ja muissa Pohjoismaissa ilmasto rajoittaa hevosten pitoa. Hevonen viettääkin suurimman osan päivästään sisätiloissa, tallissa. Tästä johtuen talliolosuhteiden mm. sisäilman laadun merkitys hevosen hyvinvoinnin osana on korostunut, verrattuna esimerkiksi Keski-Eurooppaan. Talliolojen parantamiseen ei ole kuitenkaan vielä riittävästi paneuduttu, eikä suoraan sovellettavaa tutkimustietoa ole tarpeeksi saatavilla. Osoituksena siitä, hengitystiesairaudet ovat Suomessa merkittävin hevosten terveydellinen ongelma jalkavikojen jälkeen. Lisäksi kilpailu ja harjoittelu talvisin kylmässä ilmastossa altistaa entisestään herkkää hengityselimistöä.

Hevonen on riippuvaisempi hengityselimistönsä kunnosta kuin muut tuotantoeläimet (Clarke 1987). Hevosen altistuessa talli-ilman epäpuhtauksille, saattaa sille kehittyä krooninen hengitystiesairaus eli puhkuri. Sairaus alentaa pysyvästi hevosen suorituskykyä eli hevosen 'tuotos' huononee. Lievempinä oireina huono talli-ilma aiheuttaa hengitysteiden ärsytystä, yskää, haittaavaa limaneritystä ja vastustuskyvyn alenemista. Myös allergioiden on todettu yleistyvän hevosten altistuessa epäterveelliselle talli-ilmalle (Geor 2001)

Talli-ilman epäpuhtaudet, joihin kuuluvat erilaiset hiukkaset, virukset, bakteerit, levät, sienten ja homeiden itiöt sekä punkit ovat pääosin peräisin kuivikkeista ja rehuista (Tanner ym. 1998). Myös eläimistä irtoaa pölyä ja karvoja. Hengitysilman laatuun vaikuttavia tekijöitä tallissa ovat lisäksi ilmanvaihto, siisteys ja työmenetelmät. Kuivikevalinta vaikuttaa sisäilman laatuun erityisesti pölyn ja ärsyttävien kaasujen osalta. Yleisimmin talleilla käytössä olevat kuivikkeet ovat kutterinlastu, sahanpuru ja turve. Puupohjaiset kuivikkeet häviävät turpeelle kuivikeominaisuuksissa, mutta niitä pidetään turvetta vähemmän pölyävinä ja miellyttävämpänä käyttää. Turve pidättää ja luovuttaa hyvin ravinteita ja kompostoituu nopeasti (Karlsson ym. 1998). Turvelannan loppusijoituksessa ei yleensä ole ongelmia, toisin kuin purulannan, koska se toimii maanparannusaineena.

Tutkimus toteutettiin tarkoituksena selvittää kahden eri kuivikkeen, turpeen ja kutterinlastun, vaikutuksia hevosen hyvinvointiin ja terveydentilaan. Hevosen hyvinvoinnin mittarina käytettiin kliinisin tutkimusmenetelmin arvioitua hengityselimistön terveydentilaa. Huomiota kiinnitettiin myös kavioiden kuntoon, erityisesti kosteuspitoisuuteen. Sisäilman laatua ja työntekijään kohdistuvaa altistusta seurattiin kaasumittauksin.

\section{Aineisto ja menetelmät}

Koe tehtiin MTT:n Hevostalouden yksikössä Ypäjällä syksyllä 2002. Kokeen kesto oli kolme kuukautta. Tutkimuksessa käytettiin MTT:n omistamia aikuisia suomenhevostammoja (12 yksilöä), jotka olivat iältään 5-17 -vuotiaita. Kokeen aikana hevosten ruokinta koostui esikuivatusta säilörehusta ja täysrehusta (Suomen Rehu Oy). Hevoset ruokittiin kevyen työn tarvenormien mukaisesti karkearehu-väkirehusuhteella 70:30.

Koehevosista muodostettiin koeryhmät ensimmäisen hengitystietähystyksen perusteella kokeen alussa. Tähystyksen tulosten perusteella valittiin aina kaksi oireiltaan mahdollisimman samankaltaista hevosta, jotka arvottiin eri käsittelyille. Näin meneteltiin jokaisen koehevosen kohdalla, jolloin molempiin käsittelyryhmiin saatiin kuusi hevosta. Hevoset olivat kokeen aikana yksittäiskarsinoissa saman tallin kahdella eri käytävällä, ja ulkoilivat päivittäin neljä tuntia tarhassa. Toisella käytävällä oli kuivikkeena kutterinlastua (Joutsenon Purupaali Oy) ja toisella turvetta (Vapo Oy). Kuivikkeet oli pakattu muovipaaleihin. Karsinat siivottiin päivittäin hevosten ollessa ulkona ja kuivikkeen kulutusta seurattiin.

Hengitystietähystykset ja muut mittaukset sekä näytteiden otto tehtiin alkumittauksen lisäksi kaksi kertaa kokeen aikana. Mittauskertojen väliin jäi noin 40 päivää. Hevosten hengitystieterveyttä seurattiin kokeen aikana tähystysten avulla. Tähystyksen yhteydessä otettiin henkitorvesta limanäyte, joka analysoitiin MTT:n hevossairaalan kliinisessä laboratoriossa. Limanäytteistä tehtiin solujen tarkastelu ja bakteeriviljely. Hevonen raportoitiin oireilevana mikäli sen hengitysteistä löydettiin limaa. 
Kokeessa seurattiin hevosten yleistä terveydentilaa verinäytteiden avulla sekä elintoimintoja seuraamalla. Verianalyysiin kuului pieni verenkuva, joka sisältää seuraavat määritykset: Berytrosyytit, B-leukosyytit, B-hemoglobiini ja B-hematokriitti sekä punasoluindeksit. Lisäksi määritettiin seerumin urean, raudan ja proteiinin määrä sekä fibrinogeeni ja valkosolujen erittelylaskenta. Hevosten elintoiminnot: ruumiinlämpö, hengitystiheys ja sydämen syke mitattiin kolmesti kokeen aikana ja muutoinkin tarvittaessa.. Hevosten sonnasta tehtiin parasiittitutkimus ja bakteeriviljely ja määritettiin pH. Bakteeriviljelyssä laskettiin mikroskoopilla EMB-levyltä Escherihcia coli -pesäkkeiden määrä. Verilevyltä tarkastettiin myös hemolyyttisten bakteerien määrä sekä mahdolliset home-esiintymät.

Etukavioista kerättiin näytteet kengitysten yhteydessä vuolemalla ja raspaamalla kavioainesta. Näytteet analysoitiin MTT:n Jokioisten eläinravitsemuksen laboratoriossa. Kavionäytettä kuivattiin uunissa $105^{\circ} \mathrm{C}$ :ssa kolmen vuorokauden ajan. Näytteet punnittiin 24 tunnin välein ja kuiva-aineet laskettiin jokaisella punnituskerralla sopivimman kuivausajan määrittämiseksi.

Tallissa mitattiin ammoniakki-, rikkivety- ja hiilidioksidikaasuja Drägerin ilmaisinputkimenetelmällä. Lasisesta ilmaisinputkesta katkaistiin molemmat päät ja se liitettiin käsikäyttöiseen Accuro-pumppuun. Tutkittavaa ilmaa imettiin putken läpi kyseessä olevalle kaasulle ominaisella painallusmäärällä ja tulos luettiin putkessa olevalta asteikolta. Työntekijään kohdistuvaa altistusta tutkittiin Drägerin diffuusioputkilla, jotka olivat suoraan osoittavia ja tarkoitettu henkilökohtaiseen altistusvalvontaan. Tallirakenteiden pinnoille kerääntyvää pölyä mitattiin kiinteästi asennetuilla pölyrasioilla ja ne punnittiin vetokaapissa ennen asennusta sekä pölykerääntymän kanssa. Painomuutos kertoi kerääntyneen pölyn määrän. Säähavainnot (säätilan kuvaus, ulkolämpötila, sisälämpötila ja sisäilman kosteus) kirjattiin ylös kokeen ajalta.

Esikuivatusta nurmisäilörehusta ja väkirehusta tehtiin rehuanalyysit MTT:n kemian laboratoriossa Jokioisilla. Näytteet kuivattiin ja jauhettiin, jonka jälkeen niistä määritettiin seuraavat analyysit: primäärinen ja sekundäärinen kuiva-aine, tuhka, raakavalkuainen, raakakuitu, raakarasva ja NDF-kuitu. Säilörehusta määritettiin lisäksi tuoreen rehun typpi sekä säilönnällistä laatua kuvaavat analyysit: ammoniumtyppi, liukoinen typpi, haihtuvat rasvahapot, maitohappo, muurahaishappo ja $\mathrm{pH}$.

Tilastolliset analyysit tehtiin SAS -ohjelmiston (SAS 1999) MIXED -proseduurilla. Koemallina oli satunnaistettujen täydellisten lohkojen koe toistomittauksin. Tähystystuloksien perusteella eläimet jaettiin alkumittauksen jälkeen pareihin ja parin yksilöt sijoitettiin kahdelle eri käsittelylle. Alkumittausta ei otettu malliin mukaan, koska sen sisältämä informaatio oli jo sisällytetty eläinparimuuttujaan. Vastemuuttuja (y) analysoitiin seuraavanlaisella tilastollisella mallilla:

$\mathrm{y}_{\mathrm{ijk}}=\mu+\mathrm{p}_{\mathrm{i}}+\mathrm{k}_{\mathrm{j}}+(\mathrm{px} \mathrm{k})_{\mathrm{ij}}+\mathrm{a}_{\mathrm{k}}+(\mathrm{p} \mathrm{x} \mathrm{a})_{\mathrm{ik}}+(\mathrm{kx} \mathrm{a})_{\mathrm{jk}}+\varepsilon_{\mathrm{ijk}}$

, jossa $\mu$ on yleiskeskiarvo, $\mathrm{p}_{\mathrm{i}}$ on $\mathrm{i}$ :nnen $(\mathrm{i}=1, \ldots 6)$ eläinparin satunnaisvaikutus, $\mathrm{k}_{\mathrm{j}}$ on käsittelyn $(\mathrm{j}=1$ tai 2) kiinteä vaikutus, $\mathrm{a}_{\mathrm{k}}$ on $\mathrm{k}$ :nnen ajanhetken $(\mathrm{k}=2$ tai 3$)$ kiinteä vaikutus, ja $\varepsilon_{\mathrm{ijk}}$ on jäännösvirhe. Termit $(\mathrm{p} \times \mathrm{k})_{\mathrm{ij}}, \quad(\mathrm{p} \times \mathrm{a})_{\mathrm{ik}}, \mathrm{ja}(\mathrm{k} \times \mathrm{a})_{\mathrm{jk}}$ ovat koetekijöiden yhdysvaikutuksia. Tilastolliseen malliin sovitettiin erilaisia toistomittausten kovarianssimatriiseja ja kovarianssirakenne valittiin Akaiken informaatiokriteerin perusteella. Ennen malliin sovitusta muuttujien normaalisuus tarkistettiin UNIVARIATE -proseduurilla Shaphiro-Wilkin testisuureen avulla. Myös jäännösten normaalisuus testattiin ja niitä tarkasteltiin graafisesti sovitearvoja vastaan. Muuttujien väliset erot testattiin Tukeyn testillä. 0/1 -muotoa olevat muuttujat sekä luokkamuuttujat (1...4) sisältävät niin vähän informaatiota, ettei niiden tilastollista testausta pidetty järkevänä. Näiden muuttujien osalta käytettiin kuvailevaa esittämistapaa.

\section{Tulokset ja tulosten tarkastelu}

\section{Hevosten hyvinvointia kuvaavat mittaukset}

Kokeen alkumittauksen perusteella kumpaankin käsittelyryhmään tuli kaksi hengitystieoireilevaa hevosta. Hevosen katsottiin oireilevan mikäli hengityselimistössä havaittiin limaa tähystyksen yhteydessä. Kokeen alussa oireilleet kutteriryhmän hevoset jatkoivat tähystyksien perusteella oireilua koko kokeen ajan. Kolmella muulla hevosella oli oireita jossain vaiheessa koetta. Turveryhmässä kokeen alussa oireilleista hevosista toinen oireili koko kokeen ajan ja toiselta oireet hävisivät. Kolmella muulla hevosella oli oireita jossain vaiheessa koetta. Kolmen kuukauden koejakson lopussa kutteriryhmässä oli neljä ja turveryhmässä kaksi oireilevaa hevosta. Oireilevien hevosten lukumäärä 
kasvoi sisäruokintakauden edetessä molemmissa käsittelyryhmissä. Tämä osoitti sisäruokintakauden lisäävän hengitysteihin kohdistuvaa altistusta. Oireiden lisääntyminen molemmissa ryhmissä erityisesti kokeen puolessa välissä viittaisi altistuksen johtuvan jostain muusta syystä kuin kuivikkeesta pelkästään. Kuitenkin kokeen lopussa oireilevien hevosten määrä oli kutterinlastulla kuivitettaessa suurempi.

Keuhkoputkesta otetuista limanäytteistä tehtiin bakteeriviljely ja solulaskenta. Bakteerikasvua esiintyi näytteissä runsaasti. Bakteerikasvu oli enimmäkseen tarkemmin määrittelemätöntä sekakasvua, jonka alkuperä on todennäköisesti ollut näytteen saastuminen. Kahdelta kutteriryhmään kuuluneelta hevoselta havaittiin kokeen lopussa näytteessä streptokokkia, toiselta hevoselta löytyi myös limaa tähystettäessä. Neutrofiilejä soluja limanäytteissä esiintyi niukasti tai kohtalaisesti. Yhdeltä kutteriryhmään kuuluneelta hevoselta tehtiin runsas löydös ja Curschmannin spiraaleja. Turveryhmässä kahdella hevosella oli melko runsaita neutrofiili löydöksiä, mutta hevosissa ei havaittu muita oireita hengitystiealtistuksesta. Keuhkoputken limanäytteen normaalikuvaa hevosella hallitsevat makrofagit ja muutama neutrofiili. Lisääntyneet neutrofiilit ja Curschmannin spiraalit viittaavat vahvasti krooniseen hengitystietulehdukseen (Tanner ym. 1998). Limanäytteiden perusteella yksi kutteriryhmän hevosista voitaisiin diagnostisoida puhkuriksi, mutta tauti on todennäköisesti saanut alkunsa jo ennen tätä koetta.

Verinäytteiden valkosolujen ja fibrinogeenin pitoisuuksien perusteella hevosilla ei ollut virustai bakteeriperäisiä tulehduksia kokeen aikana. Koehevosten veren hemoglobiinipitoisuudet ja punasolujen määrä nousivat lineaarisesti kokeen aikana $(\mathrm{P}<0,05)$. Arvot olivat korkeampia kutterinlastulla kuivitetussa ryhmässä, mutta ero käsittelyiden välillä ei ollut tilastollisesti merkitsevä. Myös seerumin rautapitoisuus kasvoi kokeen edetessä ja kokeen lopussa pitoisuus oli turveryhmässä suurempi, ero ei kuitenkaan ollut tilastollisesti merkitsevä.

Kokeen lopussa turvekuivituksella olleiden hevosten kavioaines oli kosteampaa $(32,6 \%)$ kuin kutterikuivituksella (30,5\%) olleiden. Hevosten kavioiden kosteuspitoisuuksissa oli tilastollisesti merkitsevä ero $(\mathrm{P}<0,05)$ eri kuivikekäsittelyiden välillä. Yleensä hevosten ongelmana on kavioiden kuivuminen, jolloin kavio menettää luonnollisen elastisuuden ja kestävyyden (Douglas 1994). Kaviomekanismin heikentyminen lisää jalkoihin kohdistuvaa rasitusta ja saattaa johtaa kavioiden halkeiluun. Hevosten kaviot olivat todennäköisesti kokeen alussa tavallista kuivemmat erittäin kuivan kesän jälkeen. Syksyn kosteat säät oletettavasti kosteuttivat kavioita, ja turvekuivitus säilytti tämän kosteuden kutterinlastua paremmin.

\section{Talli-ilman laatu ja kuivikkeiden kulutus}

Talli-ilman ammoniakkipitoisuuksissa oli huomattavia eroja kuivikkeiden välillä. Mittausajankohta oli aikainen aamu ennen karsinoiden siivousta ja kuvasi siten tilannetta pahimmillaan. Turvekäytävällä mitatut ammoniakkipitoisuudet olivat nollassa tai ainakin lähellä sitä (0-0,25 ppm), mutta kutterinlastulla kuivitetuista karsinoista mitatut arvot olivat huomattavasti suurempia (1,5-7 ppm) ja lähentelivät pitoisuuksia, jotka joissakin kokeissa on todettu eläimille haitallisiksi. Kuivikevalinta ei ole yhdentekevä myöskään talliympäristössä työskentelevän ihmisen kannalta. Henkilökohtaisissa työntekijöiden kaasumittausanalyyseissä lähestyttiin kutterikarsinoiden siivouksen aikana tasoa, jota voidaan pitää vähintäänkin arveluttavana jos työskentely on pitkäkestoista. Muunnettuna kahdeksan tunnin altistukseksi siivouksen aikana saatu altistus vastaa $\mathrm{HTP}_{8 \mathrm{~h}}$-arvoa 5,9 ppm. Kahdeksan tunnin altistuksen raja-arvo on $20 \mathrm{ppm}$ (Kemian työsuojeluneuvottelukunta 2002), joten tässä tutkimuksessa havaitut pitoisuudet jäävät reilusti sen alapuolelle. Raskaassa työssä voi elimistöön kuitenkin imeytyä poikkeuksellisia määriä epäpuhtauksia, vaikka HTP -arvo ei ylittyisikään. Lisäksi on otettava huomioon, että tallitöitä tekevissä on paljon nuoria ihmisiä, esimerkiksi erilaisissa oppilaitoksissa. Turvekarsinoiden siivouksen aikana ei ammoniakkialtistusta havaittu lainkaan. Ilmanvaihdon tehokkuutta kuvaavan hiilidioksidipitoisuuden arvoissa ei ollut merkitsevää eroa eri kuivikekäytävien välillä, ilmanvaihto oli siis molemmilla käytävillä samanlainen.

Pölymittauksien perusteella kuivikkeissa ei ollut suuria eroja pölyävyydessä, kutterinlastulla kuivitetulta käytävältä saatu pölyn määrä oli kuitenkin hieman suurempi (354 vs. $331 \mathrm{mg}$ ). Pölyn hiukkaskoolla on kokonaismäärää ratkaisevampi merkitys pölyn terveysvaikutuksiin, näkyvä pöly aiheuttaa lähinnä viihtyvyyshaittaa. Työterveyslaitoksen tutkimusten mukaan turvepöly aiheuttaa ihmisille lähinnä lieviä ärsytyspohjaisia nuhaoireita. Eläinkokeissa turvepöly on aiheuttanut keuhkoärsytystä mutta ei varsinaisia vaurioita (Vartiainen ym. 1998). Puupölyjen haittavaikutuksia on tutkittu puuta käsittelevillä työpaikoilla. Puupölyille altistumiseen liittyi syöpäsairauksien vaara, 
lisäksi puupölyt voivat aiheuttaa tulehduksellisia ja allergisia sairauksia (Kasanen 2001). Kyseisessä tutkimuksessa puupölyjen ärsytysvaikutusta lisäsi pieni hiukkaskoko, koska tutkimuskohteissa esiintyi hiontapölyä. Hevosten saamaa altistusta lisää niiden oleskelu altistavassa ympäristössä suurimman osan vuorokaudesta.

Turpeen kulutus kokeen aikana oli huomattavasti kutterinlastun kulutusta vähäisempää. Turvetta kului kolmessa kuukaudessa irtokuutiona laskettuna $37,6 \mathrm{~m}^{3}$ ja kutterinlastua $63,9 \mathrm{~m}^{3}$. Turpeen keskimääräinen hevoskohtainen viikkokulutus oli $0,52 \mathrm{~m}^{3}$ ja kutterinlastun $0,9 \mathrm{~m}^{3}$. Pienempi kulutus vähentää varastointitilan tarvetta ja lantalan kuormitusta sekä pienentää työmäärää mm. kuivikkeiden siirrossa. Pienempi käyttömäärä myös vähentää kuljetuskustannusten osuutta kuivikkeen kokonaishinnassa.

\section{Johtopäätökset}

Kokeen tulosten perusteella turve vaikuttaisi soveltuvan hevosten kuivikemateriaaliksi kutterinlastua paremmin. Sisäruokintakauden aikana hevosten hengitystieoireilu lisääntyi molemmissa käsittelyryhmissä. Hetkellisen oireilun lisääntymisen jälkeen tilanne palautui turveryhmässä alkuperäiselle tasolle, mutta kutteriryhmässä oireilu jatkui. Oireiden ei kuitenkaan voi todeta johtuvan pelkästään käytetyistä kuivikkeista vaan monet muukin seikat vaikuttavat oireiden esiintymiseen. Turvekuivitetuilla hevosilla kavioiden kosteuspitoisuus oli suurempi kuin kutterinlastulla.

Kuivikevalinta vaikuttaa talli-ilman laatuun. Turvekuivike pidätti virtsan ammoniakin lähes täydellisesti, kun taas kutterinlastulla kuivitetuissa karsinoissa pitoisuudet nousivat korkeiksi. Suurimmat ammoniakkipitoisuudet kutterikarsinoissa olivat aistittavissa myös ilman mittausvälineistöä. Tarkkaa tietoa hevosen ammoniakkiherkkyydestä ei kuitenkaan ole ja mittaukset tehtiin ajankohtana jolloin ammoniakkipaine oli suurimmillaan. Pölyn määrässä ei ollut suuria eroja eri kuivitustapojen välillä. Turvekarsinat koettiin helpommiksi siivota ja turpeen kulutus oli pienempi kuin kutterinlastun. Lopulliseen kuivikevalintaan vaikuttavat kuitenkin hyvinvointiseikkojen lisäksi myös taloudellisuus ja kuivikemateriaalin saatavuus.

\section{Kirjallisuus}

Clarke, A. F. 1987. A review of environmental and host factors in relation to equine respiratory disease. Equine Veterinary Journal 19: 435-441.

Douglas, J. 1994. Mechanical aspects of the equine hoof wall. Equine Athlete 7: 15-20.

Geor, R. 2001. Chronic respiratory disease: is there a nutrition link? In: Advances in Equine Nutrition: Nutrition and Disease. Proceedings of the 2001 Equine Nutrition Conference for Feed Manufacturers. Kentucky Equine Research, Inc. pp.127-131.

Karlsson, S., Greatorex, J.M., Tersmeden, M., Steineck, S. 1998. Composting horse manure. Influence of bedding material on ammonia emissions. Swedish Institute for Agricultural and Environmental Engineering. Uppsala, Sweden.

Kasanen, J-P., Markkanen, A., Naarala, J., Pennanen, S., Pasanen, P., Liesivuori, J. \& Pasanen, A-L. 2001. Puupölyjen ärsyttävyys, solutason vaikutukset ja haitalliseksi tunnetut pitoisuudet. Hankkeen 100098 loppuraportti Työsuojelurahastolle 2001. Kuopio, Kuopion aluetyöterveyslaitos, 64 s.

Kemian työsuojeluneuvottelukunta. 2002. HTP-arvot 2002. Työsuojelusäädöksiä 3. Sosiaali- ja terveysministeriö, työsuojeluosasto. Tampere. $57 \mathrm{~s}$.

Tanner, M.K., Swinker, A.M., Beard, M.L., Cosma, G.N., Traub-Dargatz, J.L., Martinez, A.B. \& Olenhock, S.A. 1998. Effect of phone book paper versus sawdust and straw bedding on the presence of airborne gram-negative bacteria, fungi and endotoxin in the horse stalls. Journal of Equine Veterinary Science 18: 457461.

SAS Institute Inc. 1999. SAS/STAT User's Guide, Version 8, Cary, NC: SAS Institute Inc. 3809 s.

Vartiainen, M., Jantunen, M., Willmann, P., Yli-Tuomi, T., Raunemaa, T., Marja-aho, J. \& Selin, P. 1998.

Turvetuotannon pölypäästöjen ympäristöterveysriski. Loppuraportti. Kansanterveyslaitoksen julkaisuja B11/1998. Kuopio. 35 s. 